\title{
National Assessment of Tree City USA Participation According to Geography and Socioeconomic Characteristics
}

\author{
Adam Berland, Dustin L. Herrmann, and Matthew E. Hopton
}

\begin{abstract}
Tree City USA is a national program that recognizes municipal commitment to community forestry. In return for meeting program requirements, Tree City USA participants expect social, economic, and/or environmental benefits. Understanding the geographic distribution and socioeconomic characteristics of Tree City USA communities at the national scale can offer insights into the motivations or barriers to program participation, and provide context for community forestry research at finer scales. In this study, researchers assessed patterns in Tree City USA participation for all U.S. communities with more than 2,500 people according to geography, community population size, and socioeconomic characteristics, such as income, education, and race. Nationally, $23.5 \%$ of communities studied were Tree City USA participants, and this accounted for $53.9 \%$ of the total population in these communities. Tree City USA participation rates varied substantially by U.S. region, but in each region participation rates were higher in larger communities, and long-term participants tended to be larger communities than more recent enrollees. In logistic regression models, owner occupancy rates were significant negative predictors of Tree City USA participation, education and percent white population were positive predictors in many U.S. regions, and inconsistent patterns were observed for income and population age. The findings indicate that communities with smaller populations, lower education levels, and higher minority populations are underserved regionally by Tree City USA, and future efforts should identify and overcome barriers to participation in these types of communities.

Key Words. Arbor Day Foundation; Community Forestry; Community Size; Geographic Region; Green Infrastructure; Municipal Management; Tree City USA.
\end{abstract}

Urban trees provide a wide array of environmental, social, and economic benefits (Dwyer et al. 1992; McPherson et al. 1997; Donovan and Butry 2010), such as improved stormwater management, reduced urban heat island effects, and increased property values. Most residents agree that urban trees are important and the benefits of trees outweigh the annoyances trees cause (Lohr et al. 2004; Schroeder et al. 2006). It is common for municipalities to plant and maintain trees on public land to take advantage of the benefits trees provide and to meet citizen demand for treed urban landscapes. However, community forestry programs vary widely in terms of institutional structure, tree care practices, and funding (Kuhns et al. 2005; Ries et al. 2007; Stevenson et al. 2008), which makes it difficult to gauge a municipality's dedication to community forestry. The Tree City USA (TCUSA) program addresses this difficulty by recognizing communities that demonstrate a commitment to tree planting and care (Rosenow and Yager 2007).

In the United States, TCUSA is the primary national program certifying the proactive management of community forests. TCUSA was created in 1976 and is administered by the Arbor Day Foundation in partnership with the USDA Forest Service and the National Association of State Foresters (Arbor Day Foundation 2014). Participation in the TCUSA program is voluntary, and contingent on communities meeting the following community forestry standards: 1) establishing a tree board or department with legal responsibility for tree care on municipal property; 2) enacting an ordinance to guide tree care; 3 ) committing to a community forestry program with 
an annual budget of at least USD $\$ 2$ per capita; and 4) observing Arbor Day annually (Rosenow and Yager 2007; Arbor Day Foundation 2014). These standards enable communities of all sizes to participate in the TCUSA program. Approximately 3,400 communities participate in TCUSA, and over 135 million people reside in TCUSA communities (Arbor Day Foundation 2014).

The Arbor Day Foundation cites many benefits for communities participating in the TCUSA program (Rosenow and Yager 2007; Arbor Day Foundation 2014). For instance, TCUSA participation can promote citizen education and engagement, improve public image, and attract businesses and tourists (Rosenow and Yager 2007; Arbor Day Foundation 2014). From a management perspective, meeting the TCUSA standards provides a framework for participating communities to manage their forest resources effectively, and TCUSA communities are more likely to receive forestry grants and emergency funding (Rosenow and Yager 2007; Arbor Day Foundation 2014). Finally, prioritizing urban trees yields environmental benefits, such as reduced stormwater runoff and moderation of urban temperatures (Rosenow and Yager 2007). Berland and Hopton (2014) found evidence that TCUSA communities enjoy substantially higher reductions in modeled stormwater runoff from street trees than non-participants in the same region. On the other hand, Heynen and Lindsey (2003) did not observe a relationship between tree canopy cover and TCUSA participation, but they speculated that TCUSA participation may serve an important educational role and promote increases in canopy cover over time.

Although the realized benefits of TCUSA participation have received relatively little attention in the literature, continued participation by communities nationwide suggests they are experiencing positive impacts in terms of citizen engagement and public image, a framework for urban forest management, and/or environmental outcomes. Understanding the geographic distribution and socioeconomic characteristics of TCUSA participants is a first step to understanding potentially unequal distributions of TCUSA benefits, as well as the motivating factors and barriers to participation. In this vein, limited research has been conducted at the state level. In
Maryland, U.S., more populous communities were more likely to participate in TCUSA, but participation was not related to demographic characteristics (Galvin and Bleil 2004). Similarly, Ries et al. (2007) noted that smaller communities in Oregon, U.S., were less aware of the TCUSA program.

While TCUSA participation has been analyzed for select individual states, national patterns have not been studied in depth. A national assessment of TCUSA participation was conducted to understand whether program participation varies according to geographic region, community size, or characteristics of the population. Assuming the TCUSA program offers benefits for participating municipalities, this assessment offers insight into the types of communities that are disproportionately more or less likely to enjoy the advantages of participation. In this study, the authors addressed the following questions:

- Do TCUSA participation rates vary among U.S. regions?

- Do TCUSA participation rates vary according to community population?

- Is the duration of TCUSA participation related to community population?

- Are communities more likely to participate in TCUSA if their neighbors participate?

- Are TCUSA participation rates related to community characteristics, including income, education, housing tenure, race, and age of residents?

\section{MATERIALS AND METHODS}

\section{Data Collection and Preparation}

Researchers generated a list of TCUSA participants from the Arbor Day Foundation's (2014) online directory. The directory was updated in April 2014, and the authors assumed that any changes in program participation from monthto-month had minimal impact on the findings of the study. To compare characteristics of participant and non-participant communities, a full set of so-called candidate communities, or those U.S. communities that could reasonably opt to participate in TCUSA based on community type and population, were developed. Candidate communities were identified in all fifty states, using 2012 American Community Survey (ACS) five- 
year estimate data (U.S. Census Bureau 2014). These census data were downloaded as polygon spatial data with demographic and economic variables included. For most states, researchers used census places to designate candidate communities. However, many TCUSA participants in the northeastern U.S. were not included in the census places data set, and so county subdivisions were included as TCUSA candidates in the following states: Connecticut, Massachusetts, New Hampshire, New Jersey, New York, Pennsylvania, Rhode Island, and Vermont. In these states, duplicates were removed for communities captured in both place and county subdivision data sets. A small number of counties $(\mathrm{n}=18)$ and townships $(\mathrm{n}=$ 4) from ten other states were added to the list of candidate communities because they were TCUSA participants, but these cases were rare, so other counties and townships from these states were not considered TCUSA candidate communities.

Researchers restricted the candidate community list to those communities with population $\geq 2,500$, which is the U.S. Census Bureau's threshold for an urban locale. This was done because very small communities were highly unlikely to participate in TCUSA (3.1\% participation rate for communities $<2,500$ population). This resulted in a list of candidate communities for all fifty states that included 11,355 communities $\geq 2,500$ population. Among these, 2,673 communities were TCUSA participants (Arbor Day Foundation 2014). The candidate community spatial data (U.S. Census Bureau 2014) included ACS demographic and economic data and specific variables of interest are described hereafter. A binary TCUSA participation indicator $(0=$ no, $1=$ yes $)$ was associated with each candidate community.

\section{Does TCUSA Participation Vary by U.S. Region?}

TCUSA participation rates were compared among U.S. regions. Nine regions were defined as groups of states based on U.S. Census Bureau regional divisions (Figure 1). Regions were used in recognition that there are differences in climatic, political, socioeconomic, and historical factors around the country that could impact TCUSA participation rates. For each region, researchers calculated the proportion of candidate communi- ties (population $\geq 2,500$ ) participating in TCUSA. Then Pearson's $\chi^{2}$ test was used to determine if participation rates varied among regions. When the $\chi^{2}$ test was significant, a $\chi^{2}$ post hoc test was used to identify which regions varied from the rest of the regions. Researchers accounted for multiple hypothesis testing in post hoc tests using a false discovery rate correction (Benjamini and Hochberg 1995). Significant post hoc tests indicated a region contained either a higher or a lower proportion of TCUSA participants relative to the other regions. The $\chi^{2}$ tests were performed using $\mathrm{R}$ v3.1.2 ( $\mathrm{R}$ Core Team 2014).

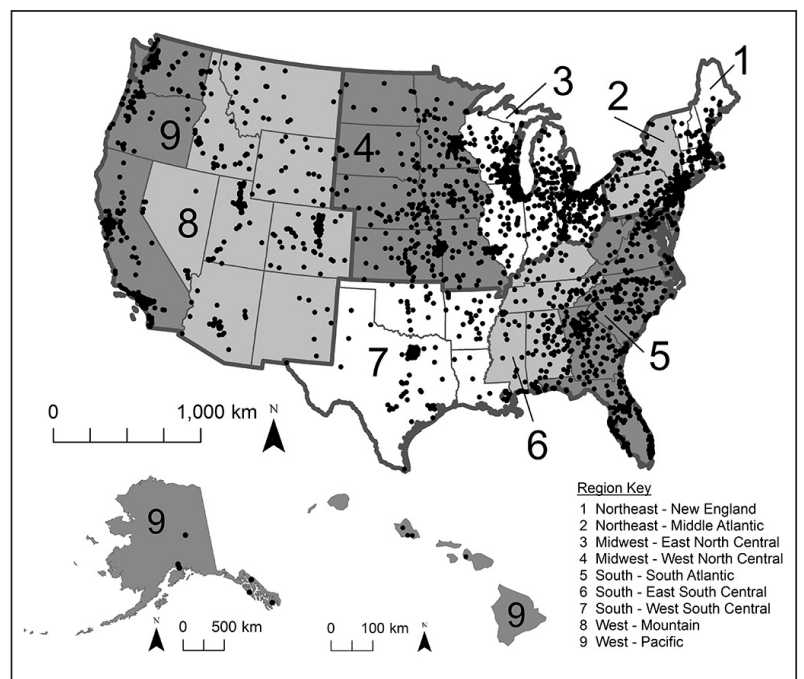

Figure 1. Tree City USA participants by U.S. region. Dots indicate Tree City USA communities over 2,500 population. Shading and numbers indicate U.S. regions. Regions were defined according to U.S. Census Bureau conventions.

\section{Is Community Population Size Related to TCUSA Participation Likelihood and Duration of Participation?}

Researchers hypothesized that larger communities would be more likely to participate in TCUSA. Logistic regression models were used to assess whether the likelihood of TCUSA participation varied according to community population. Separate models were constructed for the national data set and for each U.S. region depicted in Figure 1. In the logistic regression models, the dependent variable was a binary indicator of TCUSA participation, and community population was the independent variable. Community populations were log-transformed to meet model assumptions of normality. Spatial 
dependency was not observed in the model residuals, so researchers did not account for spatial autocorrelation in model specification. After the models were constructed, the predicted population at which a community had a 0.5 probability of participating in TCUSA was extracted.

It was hypothesized that longer-term TCUSA participants would have larger populations than more recent enrollees. A linear regression model was constructed for TCUSA participants in which log-transformed community population was the dependent variable, and the year of TCUSA adoption was the independent variable. Based on the hypothesis that larger communities would be longer-term TCUSA participants, an additional linear model was developed that included a quadratic term for the year of TCUSA adoption, as this curve may better capture a potential trend in the data introduced by saturation of TCUSA participation among larger communities. The original linear model was compared to the model with a quadratic term using the Akaike Information Criterion (AIC), where a lower AIC indicates the better model (i.e., the model that more successfully balances goodness of fit and parsimony). Logistic and linear regression models were constructed in R v3.1.2 ( $\mathrm{R}$ Core Team 2014).

\section{Are TCUSA Participants Spatially Autocorrelated?}

A join-count statistic was calculated to determine if neighboring communities were more likely to participate in TCUSA than would be expected by random chance. The join-count statistic is a measure of spatial autocorrelation typically calculated using binary data, in this case TCUSA participants (coded 1) and non-participants (coded 0). Using a matrix of candidate community neighbor relationships, the statistic measures the frequency of 1-1,0-0, and 0-1 joins and compares them to the frequencies expected under a random spatial distribution of the same number of 0 and 1 values. For the data set, the join-count statistic was used to evaluate, for each community's four nearest neighbors, whether TCUSA participants were more likely to be joined than would be expected by chance. In other words, the join-count statistic was used to assess whether TCUSA par- ticipants were spatially autocorrelated. To assess significance, the authors compared the observed join-count statistic to a Monte Carlo simulation with 9,999 randomizations. Join-count statistics were calculated in R v3.1.2 ( $\mathrm{R}$ Core Team 2014) using the spdep package (Bivand 2014).

\section{Is TCUSA Participation Related to Socioeconomic Indicators?}

Logistic regression analyses were conducted to model TCUSA participation as a function of several socioeconomic variables. In these logistic regression models, TCUSA was the binary response variable, and independent variables included the following demographic variables from the 2012 ACS five-year estimate data (U.S. Census $\mathrm{Bu}-$ reau 2014): income (median household income), education (high school graduation rate), owner occupancy (percent of housing units occupied by owner), percent white (percent of population that identifies their race as white alone), age (median population age in years), and total population. Independent variables were prescreened for excessive collinearity $(|\mathrm{r}|>0.7$; Dormann et al. 2013); this was not an issue, so all variables were included in the models. Communities with missing data values were excluded from further analysis. Separate models were constructed for each of nine census regions shown in Figure 1. A comprehensive national model was not developed because creation of a national connectivity matrix (see below) exceeded computational limits.

Inspection of logistic regression residuals indicated high spatial autocorrelation, which can lead to incorrect inferences by inflating degrees of freedom (Dormann et al. 2007). To address spatial autocorrelation in the models, the authors implemented spatial eigenvector mapping (SEVM), which has been shown to account for spatial autocorrelation in regression models (Dormann et al. 2007; Diniz-Filho et al. 2008). For each census region, spatial filters were developed using SEVM based on Gabriel connectivity matrices (following Diniz-Filho et al. 2008). These spatial filters describe the spatial arrangement of communities from the broadest patterns to increasingly finer-scaled patterns. Once extracted, the spatial filters can be included in the regression model as independent vari- 
ables to account for spatial relationships among points. The first ten spatial filters were included as independent variables alongside community socioeconomic characteristics in the construction of each region's logistic regression model. The decision to use ten spatial filters was based on sequentially adding filters until the Moran's $I$ statistic for model residuals was $<0.05$ in the first distance class (following de Oliveira and DinizFilho 2010). Overall model fit was assessed using the McFadden pseudo- $R^{2}$; this metric yields lower values than traditional $R^{2}$ calculations, as values from 0.20-0.40 represent excellent model fit (McFadden 1979). SEVM and logistic regressions were performed in SAM v4.0 (Rangel et al. 2010).

\section{RESULTS}

\section{TCUSA Participation Varies by Region}

In total, 2,673 candidate communities participated in TCUSA. These communities represented $132,271,497$ people, or $53.9 \%$ of the total population in candidate communities. Among all candidate communities, the TCUSA participation rate was $23.5 \%$, and ranged from $11.5 \%$ in the Middle Atlantic region to $44.4 \%$ in the West North Central region (Table 1). The regional comparison of TCUSA participation rates indicated highly significant differences among regions $\left(\chi^{2}=827.7, P<0.001\right)$. TCUSA participation rates were relatively low in New England, Middle Atlantic, West South Central, and Pacific regions. Conversely, participation rates were relatively high in East North Central, West North Central, and Mountain regions (Table 1).
Table 1. Tree City USA (TCUSA) participation rates by U.S. region. Chi-square post hoc tests were used to determine whether each region's participation rate was High, Low, or not significantly different (ns) from the rest of the U.S. ( $\chi^{2}$ interpretation).

\begin{tabular}{lll}
\hline Region & $\%$ TCUSA $^{\mathrm{z}}$ & $\chi^{2}$ interp. \\
\hline 1-New England & $19.2 \%$ & Low \\
2-Middle Atlantic & $11.5 \%$ & Low \\
3-East North Central & $39.7 \%$ & High \\
4-West North Central & $44.4 \%$ & High \\
5-South Atlantic & $23.1 \%$ & ns \\
6-East South Central & $23.4 \%$ & ns \\
7-West South Central & $12.1 \%$ & Low \\
8-Mountain & $39.1 \%$ & High \\
9-Pacific & $19.7 \%$ & Low \\
United States & $23.5 \%$ & \\
\hline
\end{tabular}

${ }^{\mathrm{z}}$ For communities $\geq 2,500$ population

\section{Community Population Relates to Likelihood and Duration of TCUSA Participation}

The logistic regression models predicting TCUSA participation as a function of population were highly significant $(P<0.0001)$ for the national data set (Table 2; Figure 2) and for each U.S. region (Figure 3). In each model, the likelihood of TCUSA participation increased with population. Nationally, the predicted population at which a community had a 0.5 probability of participating was 46,262, but this value varied widely among regions (Table 2).

To assess the relationship between year of TCUSA adoption and community population, researchers used a linear regression with quadratic term based on its lower AIC score $(8,573.4$ versus $8,585.2$ for the model without quadratic term). The model fit was highly significant $(P=$ $0.0002)$, but the overall explanatory power of the model was limited (adjusted $R^{2}=0.05$ ). The regres-

Table 2. Logistic regression results predicting likelihood of Tree City USA participation as a function of community population (log).

\begin{tabular}{|c|c|c|c|c|c|c|}
\hline Region & $\mathrm{n}$ & Estimate & SE & z-ratio & $P$ & $\begin{array}{l}\text { Pop. at } 0.5 \\
\text { probability }^{z}\end{array}$ \\
\hline 1-New England & 736 & 1.05 & 0.11 & 9.3 & $<0.0001$ & 54,553 \\
\hline 2-Middle Atlantic & 2,617 & 0.90 & 0.07 & 13.6 & $<0.0001$ & 96,034 \\
\hline 3-East North Central & 1,617 & 0.83 & 0.06 & 13.6 & $<0.0001$ & 15,979 \\
\hline 4-West North Central & 810 & 1.14 & 0.10 & 11.5 & $<0.0001$ & 9,922 \\
\hline 5-South Atlantic & 1,906 & 0.86 & 0.06 & 15.0 & $<0.0001$ & 48,823 \\
\hline 6-East South Central & 602 & 1.09 & 0.12 & 8.9 & $<0.0001$ & 28,405 \\
\hline 7-West South Central & 1,062 & 1.13 & 0.09 & 12.0 & $<0.0001$ & 80,731 \\
\hline 8-Mountain & 647 & 0.63 & 0.08 & 8.0 & $<0.0001$ & 22,177 \\
\hline 9-Pacific & 1,358 & 0.96 & 0.07 & 14.1 & $<0.0001$ & 79,342 \\
\hline United States & 11,355 & 0.83 & 0.02 & 35.6 & $<0.0001$ & 46,262 \\
\hline
\end{tabular}

${ }^{2}$ The predicted population at which a community has a 0.5 probability of participating in Tree City USA. 
sion indicated a positive relationship between population and duration of TCUSA participation (Figure 4). The regression curve appears to flatten in recent years, indicating the population of TCUSA adopters is stabilizing over time (Figure 4).

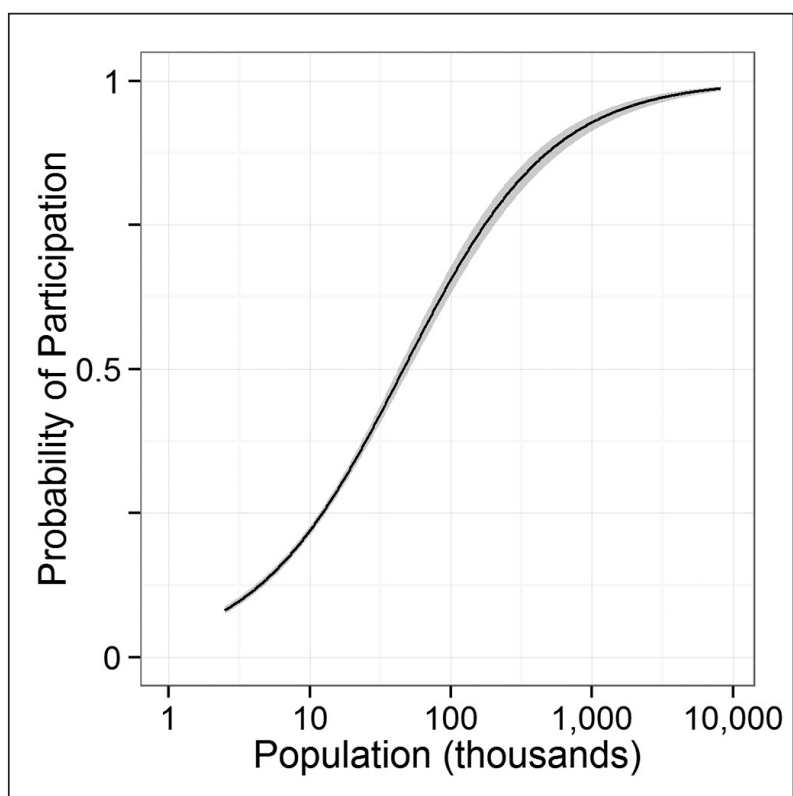

Figure 2. Logistic regression curve predicting likelihood of Tree City USA participation as a function of community population $(\mathrm{log})$. The model fit is significant at $P<0.0001$. Gray bands represent $95 \%$ confidence intervals. This regression curve applies to the national data set; see Figure 3 for regional curves.

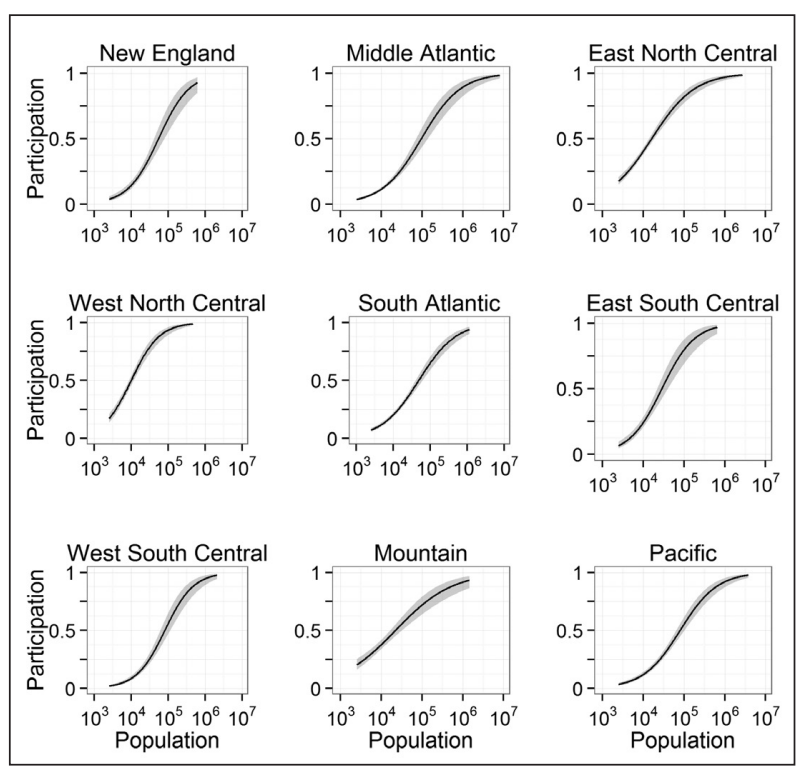

Figure 3. Regional logistic regression curves predicting likelihood of Tree City USA participation as a function of community population (log). All models are significant at $P$ $<0.0001$. Gray bands represent $95 \%$ confidence intervals. See Figure 1 for regional boundaries.

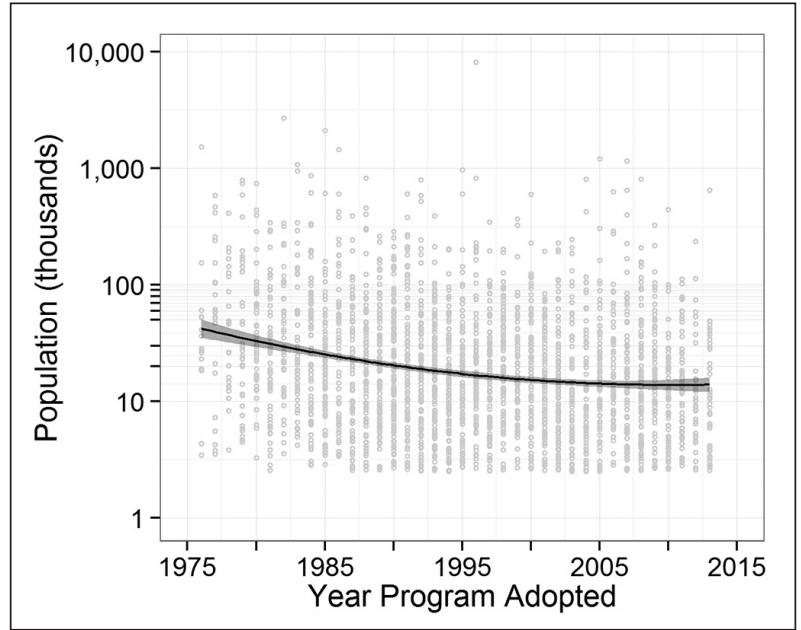

Figure 4. Regression curve describing the relationship between the duration of Tree City USA participation and the population of participant communities. Gray bands represent 95\% confidence intervals, and gray dots denote participant communities. The regression is highly significant at $P=$ 0.0002 , but overall explanatory power is modest (adjusted $R^{2}=0.05$ ). Note that population is shown on a log scale.

\section{TCUSA Participants Are Spatially Clustered}

TCUSA participant communities exhibited highly significant, positive spatial autocorrelation. The observed join-count statistic was 2,049.5 for 1-1 joins $(P=0.0001)$ and $14,090.5$ for $0-0$ joins $(P=0.0001)$; both values were higher than all data randomizations.

\section{Socioeconomic Indicators Relate to TCUSA Participation}

Logistic regression models were used to predict regional TCUSA participation. The inclusion of spatial filters as independent variables reduced residual spatial autocorrelation for each region (Moran's $I<0.05$ in the first distance class). The results of each model are shown in Table 3. In general, owner occupancy was the most consistently significant variable, as it was negatively associated with TCUSA participation in each region (i.e., TCUSA participation was generally lower where owner occupancy was higher). Total population was positively related to TCUSA participation in eight of nine regions, consistent with results presented in Figure 2 and Figure 3. Education was significantly and positively associated with TCUSA participation in seven regions, and percent white was a positive predictor in five regions (Table 3). Significant findings were not consistent for income (three pos- 
Table 3. Standardized coefficients of logistic regression to model regional predictors of Tree City USA participation. Larger standardized coefficients represent a larger effect relative to other variables in the model. Positive coefficients denote a positive effect on Tree City USA participation, and vice versa. Spatial eigenvectors used to reduce spatial autocorrelation in model residuals are not shown among the independent variables. Bold values are significant at $P<0.05$; values in bold italics are significant at $P<0.01$.

\begin{tabular}{|c|c|c|c|c|c|c|c|}
\hline \multirow[b]{2}{*}{ Region } & \multicolumn{6}{|c|}{ Standardized coefficients } & \multirow{2}{*}{$\frac{\text { Model fit }}{R_{\text {McFadden }}^{2}}$} \\
\hline & Income & Education & $\begin{array}{l}\text { Owner } \\
\text { occupancy }\end{array}$ & White & Age & Population & \\
\hline 1-New England & +1.54 & +1.43 & -3.48 & -0.78 & +0.83 & +1.23 & 0.21 \\
\hline 2-Middle Atlantic & +1.37 & +1.01 & -2.35 & -0.40 & +0.05 & +0.27 & 0.16 \\
\hline 3-East North Central & +0.79 & +1.15 & -1.54 & +0.43 & +0.19 & +5.24 & 0.15 \\
\hline 4-West North Central & +0.40 & +0.32 & -0.65 & +0.74 & -0.02 & +6.70 & 0.22 \\
\hline 5-South Atlantic & -0.80 & +0.89 & -1.03 & +0.31 & +0.40 & +6.39 & 0.21 \\
\hline 6-East South Central & +0.61 & -0.13 & -1.89 & +0.91 & +0.99 & +7.45 & 0.22 \\
\hline 7-West South Central & +0.23 & +2.86 & -1.34 & -0.04 & +0.12 & +3.29 & 0.26 \\
\hline 8-Mountain & -0.33 & +0.91 & -1.36 & +3.23 & -1.05 & +2.72 & 0.22 \\
\hline 9-Pacific & +0.28 & +1.76 & -1.40 & +0.84 & -0.72 & +2.35 & 0.15 \\
\hline
\end{tabular}

itive relationships, one negative) or population age (three positive relationships, two negative) (Table 3). Model fit was deemed excellent in six regions $\left(R_{\text {McFadden }}^{2} \geq 0.20\right)$, and acceptable in the remaining three regions $\left(R_{\text {McFadden }}^{2}=0.15-0.16\right)$ (Table 3$)$.

\section{DISCUSSION}

\section{Characteristics of TCUSA Communities}

TCUSA participation was positively associated with community population nationally (Figure 2 ) and at the regional scale (Table 3; Figure 3). Furthermore, long-term TCUSA participants had higher populations than those enrolling more recently, and the population of new enrollees appears to be leveling off over time (Figure 4). Taken together, these results indicate that while larger cities were early adopters of TCUSA and were more likely to participate overall, smaller communities are closing the participation gap slowly over time. These findings are not surprising, as research has long shown that larger cities are early adopters of innovative programs (e.g., Crain 1966) and are more likely to have municipal tree programs (Zhang and Zheng 2012). This may be attributable to multiple factors, such as higher staffing or preexisting management structures in larger municipalities that facilitated enrollment in TCUSA, or perhaps residents in larger municipalities more actively supported the implementation of community forestry programs.

Note that the analysis only considered current TCUSA participants, and thus did not account for communities that stopped participating in the program at some point. TCUSA recertification rates for 2013 were $>90 \%$ for most states (Arbor Day Foundation 2014), but it is possible that losing small numbers of participants each year would have appreciable effects over time. Regardless of how the findings are influenced by discontinued enrollments, it is apparent that larger communities are more likely to participate (Figure 2) and remain in the program over time (Figure 4).

Logistic regression analyses with socioeconomic indicators provided further insights into the characteristics of TCUSA communities. In every region, owner occupancy rate was negatively associated with TCUSA participation at $P<0.01$ (Table 3 ). This potentially can be explained by a coincidence of relatively high TCUSA participation rates and low owner occupancy rates in urban areas compared to suburban and rural areas. According to the U.S. Census Bureau (2014), national owner occupancy rates are approximately $60 \%$ in urban areas and $79 \%$ in rural areas, so the statistical finding may be indirectly indicating a higher level of TCUSA participation near urban centers. This is corroborated by positive associations between TCUSA participation and population in eight of nine U.S. regions (Table 3). While researchers did not explicitly test whether TCUSA participation was higher in metropolitan areas than rural areas, the findings regarding owner occupancy and population suggest this was indeed the case. The implication of this pattern may be that community forestry programs, in general, are encour- 
aging tree planting and maintenance where the private citizenry may be less motivated to do so. Past research has suggested that tree planting is less common on renter-occupied property because absentee property owners (who do not occupy the home) and renters (who do not own the property and may move away before benefits are realized) are both less motivated to plant trees than owner occupants (Perkins et al. 2004). By promoting publicly maintained trees, TCUSA potentially compensates in part for reduced tree planting on private property in communities with low owner occupancy rates.

Education (high school graduation rate) and percent white population were positively associated with TCUSA participation in seven and five U.S. regions, respectively (Table 3). Past research has identified instances in which tree canopy cover was distributed unequally according to education (Heynen and Lindsey 2003) and race (Landry and Chakraborty 2009). It is possible that uneven participation in TCUSA will perpetuate such inequalities in canopy cover because TCUSA requires active management and funding of community forestry programs. More broadly, if one assumes that TCUSA delivers on its goals to yield social, economic, and environmental advantages for participant communities (Arbor Day Foundation 2014), then reduced participation rates in communities with lower education levels or higher minority populations may signal regionalscale patterns of environmental injustice [for recent articles on environmental justice in the context of urban forestry, see Berland et al. (2015) and Schwarz et al. (2015)]. In other words, residents of communities with lower educational attainment or higher minority populations may not have equal access to the advantages provided by TCUSA. More information on the realized benefits of TCUSA participation (as opposed to expected or anecdotal benefits) is needed to more fully address this issue. Additional research is needed to understand why these patterns are restricted to certain regions, and why municipal leaders do not pursue TCUSA status in communities with lower educational attainment or higher minority populations. For example, is this pattern driven by scarce municipal resources, prioritization of other programming instead of community forestry, or is it attributable to a lack of program awareness, perceived benefits, or citizen interest?

\section{The Geography of TCUSA Participation}

TCUSA participation rates varied substantially among U.S. regions. The clearest national pattern was relatively low participation in the northeastern U.S. and high participation in the Midwest (compare Figure 1 and Table 1). Other patterns were less consistent. For instance, in the western U.S., participation rates were high in the Mountain region but low in the Pacific region (Table 1). The authors are unable to explain the variability in TCUSA participation rates among regions, but it is clear that opportunities exist to increase participation rates in all regions, and particularly in New England, Middle Atlantic, West South Central, and Pacific regions (Table 1).

Strategies to increase TCUSA participation likely need to be devised at regional or finer scales, because each region has unique population (Table 2; Figure 3) and socioeconomic (Table 3) profiles with respect to participation. For example, Middle Atlantic communities around 96,000 population have even odds of participating in TCUSA, whereas West North Central communities larger than 10,000 population are already more likely than not to participate (Table 2; Figure 3). As such, while it may be worthwhile to target Middle Atlantic communities around 100,000 population as new enrollees, participation may already be near saturation for larger communities in the West North Central, and efforts there may instead target smaller communities under 10,000 population. To improve the chances of success, efforts to increase participation in these two disparate regions would need to account for differences in institutional capacities between larger and smaller government units on top of other regional predilections. In light of regional differences, it may be appropriate to organize support for community forestry programs like TCUSA at the state level, perhaps through existing organizations (e.g., relevant state agencies or extension offices). State-level efforts would cast a relatively wide net while allowing for efforts to be tailored to the unique characteristics of each state.

Positive spatial autocorrelation in program participation suggests that communities are more likely to enroll in TCUSA if neighboring communities participate. This pattern could emerge spontaneously due to spatial clustering of communities with demographic profiles amenable to TCUSA participation (e.g., lower owner occu- 
pancy, higher education). Alternatively, the spatial autocorrelation could be explained by diffusion of ideas via professional networks, as municipal leaders would be more likely to share ideas with their counterparts in neighboring communities as opposed to more distant communities. Similarly, municipal leaders may feel pressure to participate in TCUSA as a means of upholding the community's prestige in relation to its neighbors. Grove et al. (2006) described this phenomenon as an "ecology of prestige" for households within a neighborhood; here, researchers potentially observed an analogous desire to keep up with neighboring communities by enrolling in TCUSA.

\section{Conclusions and Future Directions}

In the U.S., TCUSA is the most prominent program recognizing a commitment to community forestry. The study was designed to provide a national overview of TCUSA participation according to geography, community size, and socioeconomic characteristics. In the analysis, nearly one-quarter of U.S. communities $\geq 2,500$ population participated in TCUSA, and this represented over one-half of the total population in those communities. Program participation varied substantially among U.S. regions, from $11.5 \%$ of communities in the Middle Atlantic region to $44.4 \%$ in the West North Central region. TCUSA participation rates were higher in more populous communities, and long-term participants were more populous than recent enrollees. Across the majority of U.S. regions, TCUSA participation was negatively associated with owner occupancy rates, and positively associated with high school graduation rates and percent white population. These relationships could signal instances of environmental injustice if the presumed benefits of TCUSA participation are distributed unevenly with respect to educational attainment or racial composition. Patterns for income and median population age were less clear across regions. Finally, TCUSA participants exhibited positive spatial autocorrelation, as communities were more likely to participate if their neighbors participated.

This analysis represents the first national assessment of TCUSA participation, and as such, the findings provide novel insight into the characteristics of TCUSA communities. Continued research on TCUSA participation and attendant benefits will help improve community forest management, and the patterns described here can be used to frame future research questions. For example, identifying motivating factors and barriers to TCUSA participation could help gauge interest for TCUSA in non-participant communities, overcome barriers to participation, and reduce inequalities in program participation rates. In future analyses, additional factors, such as population density, existing tree canopy cover, and management responses to forest pests or changing municipal budgets, may provide insight into patterns of TCUSA participation over time and space. Finally, investigating the social (e.g., community education and engagement), economic (e.g., increased business and tourism activities), and environmental impacts (e.g., reduced stormwater runoff and urban heat island effects) of TCUSA could help quantify the advantages of participation, and may ultimately point to changes in the program that would help communities maximize the benefits associated with participation.

Acknowledgments. This research was performed while AB held a National Research Council Research Associateship Award at the U.S. Environmental Protection Agency (U.S. EPA). Partial support was provided to DLH through an appointment to the research participation program with the Oak Ridge Institute for Science and Education through the U.S. DOE and U.S. EPA. The views expressed in this article are strictly the opinions of the authors and in no manner represent or reflect current or planned policy by the U.S. EPA or other federal agencies. Mention of trade names or commercial products does not constitute endorsement or recommendation for use.

\section{LITERATURE CITED}

Arbor Day Foundation. 2014. Tree City USA. Accessed 23 February 2015. <www.arborday.org/programs/treecityusa>

Benjamini, Y., and Y. Hochberg. 1995. Controlling the false discovery rate: A practical and powerful approach to multiple testing. Journal of the Royal Statistical Society B 57:289-300.

Berland, A., and M.E. Hopton. 2014. Comparing street tree assemblages and associated stormwater benefits among communities in metropolitan Cincinnati, Ohio, USA. Urban Forestry \& Urban Greening 13:734-741.

Berland, A., K. Schwarz, D.L. Herrmann, and M.E. Hopton. 2015. How environmental justice patterns are shaped by place: Terrain and tree canopy in Cincinnati, Ohio, USA. Cities and the Environment (CATE): 8:Article 1.

Bivand, R. 2014. Spatial dependence: Weighting schemes, statistics, and models. Accessed 23 February 2015. <http://cran.r-project. org/web/packages/spdep/spdep.pdf>

Crain, R.L. 1966. Fluoridation: The diffusion of an innovation among cities. Social Forces 44:467-476. 
de Oliveira, G., and J.A.F. Diniz-Filho. 2010. Spatial patterns of terrestrial vertebrates richness in Brazilian semiarid, Northeastern Brazil: Selecting hypotheses and revealing constraints. Journal of Arid Environments 74:1418-1426.

Diniz-Filho, J.A.F., L.M. Bini, C.M. Vieira, D. Blamires, L.C. Terribile, R.P. Bastos, G. de Oliveira, and B. de Souza Barreto. 2008. Spatial patterns of terrestrial vertebrate species richness in the Brazilian Cerrado. Zoological Studies 47:146-157.

Donovan, G.H., and D.T. Butry. 2010. Trees in the city: Valuing street trees in Portland, Oregon. Landscape and Urban Planning 94:77-83.

Dormann, C.F., J. Elith, S. Bacher, C. Buchmann, G. Carl, G. Carré, J.R.G. Marquéz, et al. 2013. Collinearity: A review of methods to deal with it and a simulation study evaluating their performance. Ecography 36:27-46.

Dormann, C.F., J.M. McPherson, M.B. Araújo, R. Bivand, J. Bolliger, G. Carl, R.G. Davies, et al. 2007. Methods to account for spatial autocorrelation in the analysis of species distributional data: A review. Ecography 30:609-628.

Dwyer, J.F., E.G. McPherson, H.W. Schroeder, and R.A. Rowntree. 1992. Assessing the benefits and costs of the urban forest. Journal of Arboriculture 18:227-234.

Galvin, M.F., and D. Bleil. 2004. Relationship among tree canopy quantity, community demographics, and Tree City USA program participation in Maryland, U.S. Journal of Arboriculture 30:321-327.

Grove, J.M., A.R. Troy, J.P.M. O’Neil-Dunne, W.R. Burch, Jr., M.L. Cadenasso, and S.T.A. Pickett. 2006. Characterization of households and its implications for the vegetation of urban ecosystems. Ecosystems 9:578-597.

Heynen, N.C., and G. Lindsey. 2003. Correlates of urban forest canopy cover: Implications for local public works. Public Works Management \& Policy 8:33-47.

Kuhns, M.R., B. Lee, and D.K. Reiter. 2005. Characteristics of urban forestry programs in Utah, U.S. Journal of Arboriculture 31:285-295.

Landry, S.M., and J. Chakraborty. 2009. Street trees and equity: Evaluating the spatial distribution of an urban amenity. Environment and Planning A 41:2651-2670.

Lohr, V.I., C.H. Pearson-Mims, J. Tarnai, and D.A. Dillman. 2004 How urban residents rate and rank the benefits and problems associated with trees in cities. Journal of Arboriculture 30:28-35.

McFadden, D. 1979. Quantitative model for analyzing travel behavior of individuals: Some recent developments. pp. 279-318. In: D.A. Hensher and P.R. Stopher (Eds.). Behavioural travel modelling. Groom Helm, London, UK.

McPherson, E.G., D. Nowak, G. Heisler, S. Grimmon, C. Souch, R. Grant, and R. Rowntree. 1997. Quantifying urban forest structure, function, and value: The Chicago Urban Forest Climate Project. Urban Ecosystems 1:49-61.

Perkins H.A., N. Heynen, and J. Wilson. 2004. Inequitable access to urban reforestation: The impact of urban political economy on housing tenure and urban forests. Cities 21:291-299.

R Core Team. 2014. R: A language and environment for statistical computing. Accessed 23 February 2015. <www.R-project.org>

Rangel, T.F., J.A.F. Diniz-Filho, and L.M. Bini. 2010. SAM: A comprehensive application for Spatial Analysis in Macroecology. Ecography 33:46-50.

Ries, P.D., A.S. Reed, and S.J. Kresse. 2007. The impact of statewide urban forestry programs: A survey of cities in Oregon, U.S. Arboriculture \& Urban Forestry 33:168-175.
Rosenow, J., and M. Yager. 2007. Tree City USA. pp. 419-427. In: J.E. Kuser (Ed.). Urban and Community Forestry in the Northeast. Springer, New York, New York, U.S.

Schroeder, H., J. Flannigan, and R. Coles. 2006. Residents' attitudes toward street trees in the UK and U.S. communities. Arboriculture \& Urban Forestry 32:236-246.

Schwarz, K., M. Fragkias, C.G. Boone, W. Zhou, M. McHale, J.M. Grove, J. O'Neil-Dunne, et al. 2015. Trees grow on money: Urban tree canopy cover and environmental justice. PLoS ONE 10: $\mathrm{e} 0122051$.

Stevenson, T.R., H.D. Gerhold, and W.F. Elmendorf. 2008. Attitudes of municipal officials toward street tree programs in Pennsylvania, U.S. Arboriculture \& Urban Forestry 34:144-151.

U.S. Census Bureau. 2014. TIGER/Line with Selected Demographic and Economic Data. Accessed 23 February 2015. <www.census. gov/geo/maps-data/data/tiger-data.html>.

Zhang, Y., and B. Zheng. 2012. Urban trees programs from municipal officials' perspective: Evidence from Alabama, U.S. Arboriculture \& Urban Forestry 38:160-167.

\section{Adam Berland \\ Department of Geography \\ Ball State University \\ Muncie, Indiana 47306, U.S.}

Dustin L. Herrmann

Office of Research and Development

U.S. Environmental Protection Agency

26 W Martin Luther King Dr.

Cincinnati, Ohio 45268, U.S.

Matthew E. Hopton (corresponding author)

Office of Research and Development

U.S. Environmental Protection Agency

26 W Martin Luther King Dr.

Cincinnati, Ohio 45268, U.S.

hopton.matthew@epa.gov 
Résumé. Tree City USA est un programme national qui reconnait l'engagement municipal envers la foresterie communautaire. En contrepartie de la satisfaction aux exigences du programme, les participants à Tree City USA s'attendent à récolter des bénéfices sociaux, économiques et environnementaux. Comprendre la répartition géographique et les caractéristiques socio-économiques des communautés reconnues Tree City USA à l'échelle nationale peut fournir des pistes sur les motivations ou les contraintes à la participation audit programme, et fournir un contexte orientant la recherche en foresterie communautaire à un niveau plus précis. Dans cette étude, les chercheurs ont établi les modèles de la participation à Tree City USA pour toutes les communautés américaines de plus de 2,500 personnes selon la répartition géographique, la taille démographique de la population et les caractéristiques socio-économiques, tels le revenu, le niveau d'éducation et l'ethnie. À l'échelle nationale, $23,5 \%$ des communautés examinées participaient déjà au programme de Tree City USA, et cela représentait 53,9\% de la population totale de ces communautés. Le taux de participation à Tree City USA variait considérablement selon la région des ÉtatsUnis, mais dans chaque région le taux de participation était plus élevé parmi les plus grandes collectivités, et celles qui participaient depuis plusieurs années avaient tendance à être de plus grandes communautés que les communautés récemment inscrites. Dans les modèles de régression logistique, les taux d'occupation par les propriétaires étaient des indicateurs négatifs importants de la participation au programme Tree City USA, le niveau d'éducation et le pourcentage de la population blanche étaient quant à eux des indicateurs positifs pour de nombreuses régions des États-Unis, tandis que des modèles inconsistants furent observés en se fondant sur les revenus et les groupes d'âge. Les résultats indiquent que les communautés ayant des populations moins importantes, des niveaux d'éducation inférieurs et un nombre plus élevé de minorités sont mal desservies au niveau régional par Tree City USA et les initiatives futures devraient identifier et surmonter les obstacles à la participation de ces types de communautés.

Zusammenfassung. Tree City USA ist ein nationales Programm, welches die behördlichen Verpflichtungen zur kommunalen Fortbewirtschaftung würdigt. Im Gegenzug für die Bemühungen, die Anforderungen des Programms zu erfüllen, erwarten die Teilnehmer soziale, ökonomische und/oder ökologische Vorteile. Das Verständnis der geografischen Verteilung und sozioökonomischer Charakteristika von Tree City USA-Kommunen auf nationaler Ebene kann Einsichten in die Motivation oder Barrieren hinsichtlich der Teilnahme offerieren und liefert einen Kontext für die Erforschung kommunaler Fortwirtschaft in einem feinern Bereich. In dieser Studie untersuchen die Forscher Muster in der Tree City USA-Teilnahme für alle partizipierenden Kommunen in den USA mit mehr als 2.500 Einwohnern, entsprechend der Geografie, Kommunale Populationsdichte und sozioökonomische Charakteristika wie Einkommen, Ausbildung und Rasse. National waren 23,5\% der untersuchten Kommunen Tree City USA-Teilnehmer und das stand für $53,9 \%$ der totalen Population in diesen Kommunen. Tree City USA-Teilnehmerquoten variierten pro Region stark voneinander, aber in jeder Region war die Teilnahme in größeren Kommunen größer und Langzeitteilnehmer schienen mehr größere Kommunen zu sein als die frisch dazugekommenen. In Logistik-Regressionsmodellen sind die Raten für eine Eigentumsanwartschaft eine starke negative Vorhersage über die Teilnahme an Tree City USA, Bildungsgrad und Anteil der weißhäutigen Bevölkerung waren in vielen Regionen positive Anzeichen und unbeständige Muster wurden beobachtet für Einkommen und Populationsalter. Die Ergebnisse verdeutlichen, dass Kommunen mit kleineren Populationen, niedrigen Bildungsgraden und höheren Anteil von Minderheiten in den Populationen von Tree City USA regional unterversorgt werden und zukünftige Bemühungen sollten die Barrieren zur Teilnahme dieser Art von Kommunen identifizieren und überwinden.

Resumen. Tree City EE.UU. es un programa nacional que reconoce el compromiso municipal para la silvicultura comunitaria. A cambio de cumplir con los requisitos del programa, los participantes de Tree City USA esperan beneficios sociales, económicos y/o ambientales. La comprensión de la distribución geográfica y características socioeconómicas de las comunidades de Tree City USA a escala nacional puede ofrecer una visión de las motivaciones o barreras para participación en el programa, y proporcionar un contexto para la investigación forestal comunitaria a escalas más finas. En este estudio, los investigadores evaluaron los patrones de participación en Tree City EE.UU. para todas las comunidades de Estados Unidos, con más de 2.500 personas, según la geografía, tamaño de la población de la comunidad, y las características socioeconómicas, como el ingreso, la educación y la raza. A nivel nacional, el $23,5 \%$ de las comunidades estudiadas eran participantes de Tree City USA, y esto representó el 53,9\% de la población total en estas comunidades. Las tasas de participación en Tree City USA variaron considerablemente de una región a otra en los EE.UU., pero en cada región las tasas de participación fueron mayores en las comunidades más grandes, y los participantes a largo plazo tienden a ser las comunidades más grandes que los afiliados más recientes. En los modelos de regresión logística, las tasas de ocupación de los propietarios fueron significativamente negativos, la educación y el porcentaje de población blanca fueron positivos en muchas regiones de Estados Unidos, y no se observaron patrones inconsistentes para la edad y los ingresos de la población. Los hallazgos indican que las comunidades con menor población, niveles de educación más bajos, y las poblaciones minoritarias más altas son desatendidos regionalmente por Tree City EE.UU., y los esfuerzos futuros deberían identificar y superar los obstáculos a la participación en este tipo de comunidades. 